\title{
Mixed models identify physic nut genotypes adapted to environments with different phosphorus availability
}

\author{
P.E. Teodoro ${ }^{1}$, B.G. Laviola ${ }^{2}$, L.D. Martins ${ }^{3}$, J.F.T. Amaral ${ }^{4}$ and \\ W.N. Rodrigues ${ }^{3}$ \\ ${ }^{1}$ Departamento de Biologia Geral, Universidade Federal de Viçosa, \\ Viçosa, MG, Brasil \\ ${ }^{2}$ Laboratório de Genética e Biotecnologia, Embrapa Agroenergia, \\ Brasília, DF, Brasil \\ ${ }^{3}$ Departamento de Produção Vegetal, \\ Universidade Federal do Espírito Santo, Alegre, ES, Brasil \\ ${ }^{4}$ Departamento de Engenharia Rural, Centro de Ciências Agrárias, \\ Universidade Federal do Espírito Santo, Alegre, ES, Brasil \\ Corresponding author: P.E. Teodoro \\ E-mail: eduteodoro@hotmail.com
}

Genet. Mol. Res. 15 (3): gmr.15038429

Received January 12, 2016

Accepted April 25, 2016

Published August 18, 2016

DOI http://dx.doi.org/10.4238/gmr.15038429

Copyright (C 2016 The Authors. This is an open-access article distributed under the terms of the Creative Commons Attribution ShareAlike (CC BY-SA) 4.0 License.

\begin{abstract}
The aim of this study was to screen physic nut (Jatropha curcas) genotypes that differ in their phosphorous (P) use, using mixed models. The experiment was conducted in a greenhouse located in the experimental area of the Centro de Ciências Agrárias of the Universidade Federal do Espírito Santo, in Alegre, ES, Brazil. The experiment was arranged in a randomized block design, using a $10 \times 3$-factorial scheme, including ten physic nut genotypes and two environments that differed in their levels of soil P availability (10 and
\end{abstract}


$60 \mathrm{mg} / \mathrm{dm}^{3}$ ), each with four replications. After 100 days of cultivation, we evaluated the plant height, stem diameter, root volume, root dry matter, aerial part dry matter, total dry matter, as well as the efficiency of absorption, and use. The parameters were estimated for combined selection while considering the studied parameters: stability and adaptability for both environments were obtained using the harmonic mean of the relative performance of the predicted genotypic values. High genotype by environment interactions were observed for most physic nut traits, indicating considerable influences of $\mathrm{P}$ availability on the phenotypic value. The genotype Paraíso simultaneously presented high adaptability and stability for aerial part dry matter, total dry matter, and $\mathrm{P}$ translocation efficiency. The genotype CNPAE-C2 showed a positive response to $\mathrm{P}$ fertilization by increasing both the total and aerial part dry matter.

Key words: Jatropha curcas; Plant nutrition; REML/BLUP

\section{INTRODUCTION}

The high energy demand on and intense pollution from petroleum derivatives have stimulated worldwide research for renewable and lower environmental impact energy sources (Reis et al., 2015). In this context, physic nut oil (Jatropha curcas L.) has been appointed as an alternative source for the production of biofuels in Brazil (Durães et al., 2011; Laviola et al., 2014). This is due to its physical and chemical characteristics, which are favorable to producing biodiesel and aviation bio-kerosene, with oleic-linoleic acid levels ranging from 22 to $42 \%$ (Wani et al., 2012).

Physic nut is a perennial oilseed belonging to the Euphorbiaceae family that has a potential yield ranging from 1.2 to $1.5 \mathrm{Mg} / \mathrm{ha}$ of oil from its 4th year of age (Laviola et al., 2014). Although promising, genetically improved varieties that may ensure this potential are needed. The heterogeneity found in grown materials today suggests that this species is promising for large scale planting (Dias et al., 2007). Because it is a long-lived oilseed, Jatropha is still not considered a domesticated species and important studies of its germplasm are needed for plant selection and development of commercial varieties (Achten et al., 2010).

Phosphorus $(\mathrm{P})$ is the most limiting nutrient for plant biomass production in tropical soils, especially the Brazilian Cerrado soils (Resende et al., 2007). In a review of strategies for improving the P absorption efficiency (ABE), Ramaekers et al. (2010) reported seven mechanisms that provide plant adaptability to low $\mathrm{P}$ availability. These are increased rootto-shoot length, redistribution of growth between root types, stimulation of fine root growth $(\leq 2 \mathrm{~mm}$ in diameter), adaptation of the root architecture, soil exploration at lower metabolic expenditure, association with arbuscular mycorrhizal fungi, and increased expression of transporters with high P affinity (Ramaekers et al., 2010). The best solution for increasing yield and reducing costs due to the use of fertilizers is to identify genotypes that are best suited for each cropping system (Martins et al., 2015b).

Genetic variability is one of the main factors that promote differences in mineral nutrition within species. It allows for selection of genotypes with high nutritional efficiency, by exploiting the genetic control of the trait of interest (Fageria, 1998; Martins et al., 2015a).

Genetics and Molecular Research 15 (3): gmr.15038429 
Information about the extent to which the phenotypic variability is heritable and the main types of gene actions involved in trait inheritance help the breeder in choosing the most suitable breeding methods.

Assessment of physic nut genotypes in environments with low and high P availability allows for identification of genotypes able to grow in tropical soils, as well as genotypes more responsive to P fertilizer (Laviola and Dias, 2008). Studies on physic nut genotypes have been conducted to explore the genetic variability of traits related to efficient $P$ use (Amaral et al., 2012; Martins et al., 2015a). However, this has proven to be a complex task due to the inheritance of traits related to P uptake, which are usually polygenic and highly dependent on the environment.

Methodology involving mixed models, for example restricted maximum likelihood/ best linear unbiased prediction (REML/BLUP), allows for the evaluation of the adaptability and stability of traits, simultaneously considering environments with high and low P availability. Unlike other methods, this methodology generates results in the same unit as the assessed trait (or range of traits) themselves, which can be interpreted directly as genetic values. Moreover, this method allows for additional inferences, such as selection of genotypes specific for each environment as well as genotypes adapted and stable in both environments (Rosado et al., 2012). The aim of this study was to screen physic nut genotypes that are more or less efficient in $\mathrm{P}$ use, using mixed model methodology.

\section{MATERIAL AND METHODS}

The experiment was conducted from December 2010 to February 2011, in a greenhouse located at the experimental area of the Centro de Ciências Agrárias of the Universidade Federal do Espírito Santo, in Alegre, ES, Brazil $\left(20^{\circ} 45^{\prime} \mathrm{S}, 41^{\circ} 33^{\prime} \mathrm{W}\right.$, at an altitude of 136.2 $\mathrm{m})$. The experiment was arranged in a randomized block design, in a $10 \times 3$-factorial scheme, including ten physic nut genotypes from different regions of Brazil (Paraíso, Jales, CNPAE-C2, CNPAE-G2, CNPAE-167, CNPAE-200, CNPAE-210, CNPAE-315, CNPAE-1501, and CNPAE-08001). We included two environments differing in the level of $P$ availability in the soil $\left(10\right.$ and $\left.60 \mathrm{mg} / \mathrm{dm}^{3}\right)$ and each replicate consisted of one pot in which four seeds were sown. After germination, when the seedlings were approximately seven inches tall; each experimental plot was thinned to one plant per pot.

The physic nut seeds (from half-sib families) used in this study were provided by germplasm bank from Embrapa Agroenergia (harvested in 2010), and processed by removing immature and damaged seeds. The seeds were packaged and stored in a refrigerator $\left(3^{\circ} \mathrm{C}\right)$ until use, the water content was maintained between $10-12 \%$. The seeds were sown in plastic pots containing $10 \mathrm{dm}^{3}$ of soil collected at a depth of $20-40 \mathrm{~cm}$, with the first $20 \mathrm{~cm}$ of the soil being discarded to reduce the effect of organic matter present on the surface layer. A soil sample was sent to the laboratory for chemical and physical analyses, according to EMPRABA (1997). The soil was classified as a clayed red-yellow oxisol (EMPRABA, 2006) with the following characteristics: pH: 5.40; P: $2.00 \mathrm{mg} / \mathrm{dm}^{3} ; \mathrm{K}: 93 \mathrm{mg} / \mathrm{dm}^{3} ; \mathrm{Ca}: 1.70 \mathrm{cmol}_{\mathrm{c}} / \mathrm{dm}^{3} ; \mathrm{Mg}: 1.10 \mathrm{cmol}_{\mathrm{c}} /$ $\mathrm{dm}^{3} ; \mathrm{H}+\mathrm{Al}: 2.10 \mathrm{cmol}_{\mathrm{c}} / \mathrm{dm}^{3}$; sum of bases $3.37 \mathrm{cmol}_{\mathrm{c}} / \mathrm{dm}^{3}$; and base saturation: $61.80 \%$.

Fertilization was applied according to recommendation for controlled environmental studies (Novais et al., 1991). N and K fertilization was performed in four cover applications, the first at 20 days after sowing, and the others, at an interval of 20 days. During all fertilizations, the nutrients were supplied via soluble salts $\left(\mathrm{KNO}_{3}, \mathrm{KH}_{2} \mathrm{PO}_{4}, \mathrm{NH}_{4} \mathrm{NO}_{3}\right.$, and $\mathrm{CaHPO}$ ), seeking to ensure a nutritional balance of the soil.

Genetics and Molecular Research 15 (3): gmr.15038429 
To determine which phosphoric fertilization would provide the desired $\mathrm{P}$ levels available in the soil $\left(10\right.$ and $\left.60 \mathrm{mg} / \mathrm{dm}^{3}\right)$; a curve for $\mathrm{P}$ availability was made according to methodology proposed by Machado et al. (2011). Based on this curve, P fertilization was performed before planting, using a solution of $\mathrm{KH}_{2} \mathrm{PO}_{4}$ salt diluted in water, which was mixed into the entire volume of soil, with 0.22 and $1.75 \mathrm{~g} / \mathrm{dm}^{3}$, respectively, being applied to reach the desired soil solution P levels $\left(10\right.$ and $\left.60 \mathrm{mg} / \mathrm{dm}^{3}\right)$. Irrigation was performed daily throughout the experiment, to maintain the soil moisture near $60 \%$ of the total pore volume, as measured by particle density and soil density determination using the cylinder method according to EMPRABA (1997).

After 100 days of cultivation, we evaluated the following traits: plant height $(\mathrm{PH}, \mathrm{cm})$, stem diameter $(\mathrm{SD}, \mathrm{mm})$, root volume $\left(\mathrm{RV}, \mathrm{cm}^{3}\right.$ per plant), root dry matter (DMR), aerial part dry matter (DMA), and total dry matter (TDM, g). PH was measured using a graded ruler and SD was measured at the stem base using a digital caliper. The stems were cut at the soil level and the leaves were removed manually to obtain dry matter. The roots were extracted from the soil and washed in water. The RV was then obtained using a measuring cylinder. Vegetal material (leaves, stems, and roots) was placed separately in paper bags and dried in an oven with forced air circulation at $60^{\circ} \mathrm{C}$, until constant weight.

After drying, the DMR, DMA, and TDM were determined, using an analytical precision balance and ground separately in a Wiley-type mill, for subsequent quantification of the $\mathrm{P}$ level and content. The $\mathrm{P}$ concentrations were determined after digestion of the plant material in a nitric-perchloric acid solution (EMPRABA, 1997). The following indices were calculated for dry matter and nutrient content in the plant: a) ABE, according to Swiader et al. (1994); b) P translocation efficiency (TRE), according to Li et al. (1991); and c) P use efficiency (USE), according to Siddiqi and Glass (1981).

Data were analyzed by mixed linear model (REML/BLUP) analysis, using the following statistical model (Resende, 2007):

$$
\mathrm{Y}=\mathrm{Xb}+\mathrm{Zg}+\mathrm{Wc}+\mathrm{e}
$$

where $y$ is the data vector, $b$ is the vector of fixed-effect data (average blocks through local), $g$ is the genotypic effects of clones (random effect), $c$ is the effect of the genotype by environment interaction (random effect) and $e$ is the residual error (random effect). The parameters $X, Z$, and $W$ are the incidence matrices for $\mathrm{b}, \mathrm{g}$ and $\mathrm{c}$, respectively. The parameters were estimated for the combined selection while considering the studied parameters; stability and adaptability for both environments were obtained based on the harmonic mean of the relative performance of the predicted genotypic values. Analyses were performed using the SELEGEN-REML/ BLUP software (Resende, 2007).

\section{RESULTS}

All the variables presented coefficient of variation $\left(\mathrm{CV}_{\mathrm{e}}\right)$ lower than $14 \%$, which indicates a high experimental precision of the essay (Table 1). Associated with this result, the high estimated values $(>0.70 \%)$ for the coefficient of genetic variation $\left(\mathrm{CV}_{\mathrm{g}}\right)$ indicate that a considerable fraction of the genotypic variance $\left(\sigma_{\mathrm{g}}^{2}\right)$ was extracted from the phenotypic variance $\left(\sigma_{p}^{2}\right)$, which was higher for all variables. Based on the magnitude of $\mathrm{CV}_{\mathrm{e}}$ and $\mathrm{CV}_{\mathrm{g}}$, the results indicate the possibility of screening genotypes based on the PH, SD, DMR and TDM, for which the genetic accuracy $\left(\hat{\mathrm{r}}_{\mathrm{g} \hat{\mathrm{g}}}\right)$ was higher than $70 \%$ (Resende, 2007).

Genetics and Molecular Research 15 (3): gmr.15038429 
Table 1. Estimated genetic parameters (REML individual) for plant height (PH), stem diameter (SD), root volume (RV), root dry matter (DMR), aerial part dry matter (DMA), total dry matter (TDM), absorption efficiency (ABE), translocation efficiency (TRE), and use efficiency (USE) of genotypes of physic nut (Jatropha curcas), cultivated in environments with different levels of P supply.

\begin{tabular}{l|c|c|c|c|c|c|c|c|c}
\hline Parameter & PH & SD & RV & DMR & DMA & TDM & ABE & TRE & USE \\
\hline$\hat{\sigma}_{\mathrm{g}}^{2}$ & 4.07 & 0.39 & 73.39 & 4.59 & 6.76 & 22.96 & 0.22 & 0.27 & 1.30 \\
\hline$\hat{\sigma}_{\mathrm{c}}^{2}$ & 2.95 & 0.56 & 128.15 & 6.28 & 14.11 & 31.93 & 1.32 & 14.59 & 44.07 \\
\hline$\hat{\sigma}_{\mathrm{e}}^{2}$ & 1.23 & 0.69 & 226.46 & 1.76 & 4.08 & 10.57 & 49.93 & 24.26 & 14.59 \\
\hline$\hat{\sigma}_{\mathrm{p}}^{2}$ & 8.26 & 1.65 & 428.01 & 12.63 & 24.96 & 65.47 & 51.46 & 39.13 & 59.96 \\
\hline$\hat{\mathrm{h}}_{\mathrm{g}}^{2}$ & 0.49 & 0.23 & 0.17 & 0.36 & 0.27 & 0.35 & 0.01 & 0.01 & 0.02 \\
\hline$\hat{\mathrm{h}}_{\mathrm{mg}}^{2}$ & 0.71 & 0.51 & 0.44 & 0.57 & 0.47 & 0.57 & 0.03 & 0.03 & 0.05 \\
\hline$\hat{\mathrm{r}}_{\mathrm{gg}}$ & 0.84 & 0.71 & 0.66 & 0.75 & 0.68 & 0.75 & 0.18 & 0.16 & 0.23 \\
\hline $\mathrm{c}^{2}$ & 0.35 & 0.34 & 0.30 & 0.49 & 0.56 & 0.48 & 0.03 & 0.37 & 0.73 \\
\hline$\hat{\mathrm{r}}_{\mathrm{gloc}}$ & 0.58 & 0.40 & 0.36 & 0.42 & 0.32 & 0.41 & 0.14 & 0.02 & 0.02 \\
\hline $\mathrm{CV}(\%)$ & 4.14 & 2.28 & 7.96 & 11.28 & 5.88 & 7.67 & 7.41 & 0.76 & 2.88 \\
\hline $\mathrm{CV}(\%)$ & 2.28 & 3.05 & 13.99 & 6.98 & 4.57 & 5.21 & 11.21 & 7.11 & 9.65 \\
\hline Mean & 48.69 & 27.37 & 107.49 & 19.00 & 44.19 & 62.40 & 6.35 & 69.31 & 39.55 \\
\hline$\sigma^{2}:$ & & & & & & & & & \\
\hline
\end{tabular}

$\sigma_{\mathrm{g}}^{2}$ : genotypic variance; $\sigma_{\mathrm{c}}^{2}$ : interaction variance; $\sigma_{\mathrm{e}}^{2}$ : residual variance; $\sigma_{\mathrm{p}}^{2}$ : phenotypic variance; $\hat{\mathrm{h}}_{\mathrm{g}}^{2}$ : coefficient of heritability (broad aspect); $\hat{\mathrm{h}}_{\mathrm{mg}}{ }_{\mathrm{m}}$ : mean heritability of the genotypes; $\hat{\mathrm{r}}_{\mathrm{g} \mathrm{g}}$ : selection accuracy; $\mathrm{c}^{2}$ : coefficient of determination for the interaction effects; $\hat{\mathrm{r}}_{\text {gloc }}$ : genotypic correlation through environments; $\mathrm{CV}_{\mathrm{g}}$ : coefficient of genetic variation; $\mathrm{CV}_{\mathrm{e}}$ : coefficient of experimental variation.

The $\hat{\mathrm{h}}^{2}$ mg is estimated using the mean of the blocks as evaluation or selection criteria (Resende, 2007). Following this criterion, $\mathrm{PH}$ is considered the best to screening superior genotypes, due to the fact that this trait showed $\sigma_{\mathrm{g}}^{2}>\sigma_{\mathrm{c}}^{2}$, representing $49 \%$ of the phenotypic variation $\left(\sigma_{g}^{2} / \sigma_{p}^{2}\right)$.

High $\sigma_{c}^{2}$ were observed for most physic nut traits, indicating that the interaction between genotype and environment considerably influences the phenotypic value (Maia et al., 2009). This fact can be also confirmed by the values of $\hat{r}_{\text {gloc }}$. Variation in the level of genetic adaptability and stability of the individuals may boost the phenotypic expression of a trait (Bastos et al., 2007) that is linked to the total variation due to the interaction between the genotype and the environment.

Several changes in the relative classification of the physic nut genotypes occurred depending on the trait and the environment in which it was evaluated (Table 2). The genotype CNPAE-C2 presented the highest PH in both environments. When cultivated with enriched $\mathrm{P}$ supply, this genotype also showed the highest DMA and TDM. Under restricted P levels, the genotype CNPAE-315 presented higher SD, RV, DMR, and USE, as well as high estimated values of adaptability and stability for these traits (Table 3 ).

The genotype Paraíso presented the highest DMA, TDM, and TRE under low P availability (Table 2). This was also the genotype with the second highest values for these traits in the environment with high P supply. Regardless of the environment, the genotype CNPAE-G2 presented the highest ABE (Table 2), and, consequently, showed the highest adaptability and stability for this trait (Table 3 ).

Genetics and Molecular Research 15 (3): gmr.15038429 
Table 2. Ranking of genotypes of physic nut (Jatropha curcas) regarding the genotypic values for plant height $(\mathrm{PH})$, stem diameter (SD), root volume (RV), root dry matter (DMR), aerial part dry matter (DMA), total dry matter (TDM), absorption efficiency (ABE), translocation efficiency (TRE), and use efficiency (USE), cultivated in environments with different levels of $\mathrm{P}$ supply: low phosphorus (Environment 1, -P), high phosphorus (Environment 2, $+\mathrm{P}$ ).

\begin{tabular}{|c|c|c|c|c|c|c|c|c|c|}
\hline \multirow[t]{2}{*}{ Genotype } & $\mathrm{PH}$ & SD & RV & DMR & DMA & TDM & $\mathrm{ABE}$ & TRE & USE \\
\hline & \multicolumn{9}{|c|}{ Environment $1(-\mathrm{P})$} \\
\hline CNPAE-G2 & 7 & 10 & 10 & 3 & 4 & 4 & 1 & 8 & 4 \\
\hline CNPAE-1501 & 10 & 9 & 4 & 7 & 7 & 6 & 5 & 4 & 8 \\
\hline CNPAE-167 & 6 & 5 & 8 & 10 & 9 & 10 & 2 & 2 & 9 \\
\hline CNPAE-315 & 4 & 1 & 1 & 1 & 3 & 3 & 10 & 10 & 1 \\
\hline CNPAE-210 & 8 & 4 & 6 & 6 & 8 & 8 & 7 & 5 & 6 \\
\hline CNPAE-200 & 5 & 2 & 3 & 2 & 2 & 2 & 9 & 6 & 2 \\
\hline CNPAE-08001 & 9 & 3 & 9 & 9 & 10 & 9 & 4 & 7 & 10 \\
\hline Paraíso & 3 & 7 & 5 & 5 & 1 & 1 & 3 & 1 & 3 \\
\hline CNPAE-C2 & 1 & 6 & 7 & 4 & 6 & 5 & 6 & 9 & 7 \\
\hline \multirow[t]{2}{*}{ Jales } & 2 & 8 & 2 & 8 & 5 & 7 & 8 & 3 & 5 \\
\hline & \multicolumn{9}{|c|}{ Environment $2(+\mathrm{P})$} \\
\hline CNPAE-G2 & 8 & 10 & 10 & 8 & 8 & 10 & 1 & 10 & 10 \\
\hline CNPAE-1501 & 10 & 3 & 1 & 3 & 7 & 6 & 2 & 8 & 8 \\
\hline CNPAE-167 & 5 & 4 & 4 & 7 & 10 & 8 & 5 & 7 & 9 \\
\hline CNPAE-315 & 3 & 2 & 3 & 2 & 3 & 3 & 9 & 6 & 4 \\
\hline CNPAE-210 & 6 & 1 & 4 & 9 & 6 & 7 & 6 & 4 & 7 \\
\hline CNPAE-200 & 2 & 5 & 2 & 1 & 9 & 5 & 10 & 9 & 6 \\
\hline CNPAE-08001 & 9 & 9 & 9 & 10 & 5 & 9 & 3 & 1 & 1 \\
\hline Paraíso & 7 & 7 & 5 & 5 & 2 & 2 & 7 & 2 & 2 \\
\hline CNPAE-C2 & 1 & 6 & 6 & 6 & 1 & 1 & 4 & 3 & 3 \\
\hline Jales & 4 & 8 & 8 & 4 & 4 & 4 & 8 & 5 & 5 \\
\hline
\end{tabular}

Table 3. Adaptability and stability regarding the genotypic values for plant height (PH), stem diameter (SD), root volume (RV), root dry matter (DMR), aerial part dry matter (DMA), total dry matter (TDM), absorption efficiency (ABE), translocation efficiency (TRE), and use efficiency (USE), of 10 genotypes of physic nut (Jatropha curcas), cultivated in environments with different levels of phosphorus supply.

\begin{tabular}{l|c|c|c|c|c|c|c|c|c}
\hline Genotype & PH & SD & RV & DMR & DMA & TDM & ABE & TRE & USE \\
\hline CNPAE-G2 & 46.91 & 26.05 & 86.05 & 19.66 & 43.29 & 55.28 & $\mathbf{7 . 0 4}$ & 65.11 & 30.82 \\
\hline CNPAE-1501 & 44.78 & 27.26 & 114.40 & 19.43 & 43.12 & 61.82 & 6.35 & 68.62 & 36.47 \\
\hline CNPAE-167 & 48.38 & 27.70 & 103.96 & 15.04 & 38.11 & 53.41 & $\mathbf{6 . 3 6}$ & $\mathbf{7 0 . 2 7}$ & 31.54 \\
\hline CNPAE-315 & 49.71 & $\mathbf{2 8 . 8 2}$ & $\mathbf{1 1 9 . 1 9}$ & $\mathbf{2 2 . 3 2}$ & 45.31 & 67.67 & 6.15 & 67.35 & $\mathbf{4 5 . 0 5}$ \\
\hline CNPAE-210 & 47.65 & $\mathbf{2 8 . 2 3}$ & 110.52 & 18.07 & 42.30 & 60.31 & 6.26 & 69.80 & 38.81 \\
\hline CNPAE-200 & 49.92 & 27.49 & $\mathbf{1 1 7 . 0 4}$ & $\mathbf{2 2 . 5 9}$ & 44.93 & 67.62 & 6.14 & 67.17 & $\mathbf{4 4 . 2 0}$ \\
\hline CNPAE-08001 & 46.79 & 27.05 & 92.29 & 13.08 & 39.97 & 54.00 & 6.34 & 72.72 & 37.29 \\
\hline Paraíso & 48.95 & 26.93 & 111.70 & 19.42 & $\mathbf{5 0 . 9 8}$ & $\mathbf{7 0 . 3 5}$ & 6.31 & $\mathbf{7 1 . 4 1}$ & 43.73 \\
\hline CNPAE-C2 & $\mathbf{5 3 . 1 1}$ & 27.38 & 107.88 & 20.02 & $\mathbf{4 7 . 8 4}$ & $\mathbf{6 7 . 9 7}$ & 6.31 & 70.01 & 41.04 \\
\hline Jales & $\mathbf{5 0 . 5 5}$ & 26.82 & 108.43 & 18.68 & 44.75 & 63.39 & 6.23 & 69.97 & 41.49 \\
\hline
\end{tabular}

Bold values indicate the two best genotypes for each trait.

\section{DISCUSSION}

The genetic parameters indicate that the interaction between genotype and environment considerably influences the phenotypic value (Maia et al., 2009). This fact partially explains the differential response of the physic nut genotypes when cultivated in environments differing in P supply (Amaral et al., 2012; Martins et al., 2015a). The explanation for the different behaviors of physic nut genotypes regarding their tolerance to low and high soil P supply (Table 2) is related to the wide genetic variability found in this species, as has been reported in several studies (Wani et al., 2012; Laviola et al., 2014; Martins et al., 2015a; Reis et al., 2015).

Genetics and Molecular Research 15 (3): gmr.15038429 
The CNPAE-C2 genotype, which presented the highest PH, regardless of P supply, and the highest DMA and TDM, when cultivated in the environment with high P supply, indicates that this genotype may be responsive to the fertilization with P (Amaral et al., 2012; Martins et al., 2015a).

The CNPAE-315 genotype developed a larger root system when cultivated in the P-limited environment. This behavior may be a strategy to explore a larger soil volume in an attempt to find and absorb more P (Grant et al., 2001). The opposite has been observed in other genotypes and species, as described by Marschner (1995). This suggests that root growth may be inhibited under deficiency of $P$, resulting in a decreased allocation of carbohydrates to the roots. This is indicated by the increase in sucrose concentration in plant tissues. Furthermore, the CNPAE-315 genotype showed highest adaptability and stability for SD, RV, and P USE and the second highest adaptability and stability for DMR.

The Paraíso genotype presented the highest adaptability and stability for the DMA, TDM, and P TRE, indicating that this genotype may have a high adaptability to P-deficient environments as well as to environments with adequate concentrations of this nutrient.

The P ABE is the capacity of the plants in accumulate $\mathrm{P}$ in the biomass, even under conditions of low soil $\mathrm{P}$ availability. This trait is a multigene trait that varies between species and even among genotypes of the same species (Föhse et al., 1988). Since ABE is the ratio between the nutrient content in the plant and the root dry matter, the genotype CNPAE-315 obtained the lowest ranking for this trait. Similar results have been obtained by Amaral et al. (2012), who verified that limited $\mathrm{P}$ supply promotes root growth of some genotypes of physic nut.

Based on morphological characters, we have identified more stable genotype (Paraíso) as the availability of $\mathrm{P}$ and genotype (CNPAE-C2) that is responsive to environments with high P. These results will contribute to expansion of the cultivation of this crop in the Brazilian Cerrado and biofuel production in the country, especially in land-scarce P. It is important to mention that for future studies it would be interesting to evaluate the most promising genotypes identified in this paper under intermediate doses of $\mathrm{P}$.

\section{Conflicts of interest}

The authors declare no conflict of interest.

\section{ACKNOWLEDGMENTS}

We thank the National Council for Scientific and Technological Development (CNPq) for financial support.

\section{REFERENCES}

Achten WMJ, Nielsen LR, Aerts R, Lengkeek AG, et al. (2010). Towards domestication of Jatropha curcas. Biofuels 1: 91-107. http://dx.doi.org/10.4155/bfs.09.4

Amaral JFT, Martins LD, Laviola BG, Christo LF, et al. (2012). A differential response of physic nut genotypes regarding phosphorus absorption and utilization is evidenced by a comprehensive nutrition efficiency analysis. J. Agric. Sci. 4: 164-173.

Bastos IT, Barbosa MHP, Resende MDV, Peternelii LA, et al. (2007). Avaliação da interação genótipo x ambiente em cana-de-açúcar via modelos mistos. Pesq. Agropec. Trop. 37: 195-203.

Dias LAS, Leme LP, Laviola BG, Pallini Filho A, et al. (2007). Cultivo de pinhão-manso (Jatropha curcas L.) para produção de óleo combustível. Viçosa, MG, 2007.

Durães FOM, Laviola BG and Alves AA (2011). Potential and challenges in making physic nut (Jatropha curcas L.) a

Genetics and Molecular Research 15 (3): gmr.15038429 
viable biofuel crop: the Brazilian perspective. CAB Rev.: Perspec. Agric. Vet. Sci. Nut. Nat. Resour. 6: 1115-1122. http://dx.doi.org/10.1079/PAVSNNR20116043

EMBRAPA - Empresa Brasileira de Pesquisa Agropecuária (1997). Manual de métodos de análises de solo. 2nd edn. Rio de Janeiro.

EMBRAPA - Empresa Brasileira de Pesquisa Agropecuária (2006). Sistema brasileiro de classificação de solos. 2nd edn. Rio de Janeiro.

Fageria NK (1998). Otimização da eficiência nutricional na produção das culturas. Rev. Bras. Eng. Agric. Amb. 2: 6-16. http://dx.doi.org/10.1590/1807-1929/agriambi.v02n01p6-16

Föhse D, Claassen N and Jungk A (1988). Phosphorus efficiency of plants: External and internal P requirement and P uptake efficiency of different plant species Plant Soil 10: 101-109. http://dx.doi.org/10.1007/BF02143545

Grant CA, Platen DN, Tomaziewicz DJ and Sheppard SC (2001). A importância do fósforo no desenvolvimento inicial da planta. POTAFOS, Piracicaba, 1-5.

Laviola BG and Dias LAS (2008). Teor e acúmulo de nutrientes em folhas e frutos de pinhão-manso. Rev. Bras. Cienc. Solo 32: 1969-1975. http://dx.doi.org/10.1590/S0100-06832008000500018

Laviola BG, Silva SDA, Juhász ACP, Rocha RB, et al. (2014). Desempenho agronômico e ganho genético pela seleção de pinhão - manso em três regiões do Brasil. Pesq. Agropec. Bras. 49: 356-363. http://dx.doi.org/10.1590/S0100204X2014000500005

Li B, McKeand SE and Allen HL (1991). Genetic variation in nitrogen use efficiency of loblolly pine seedlings. Forest Sci. 37: 613-626.

Machado VJ, Souza CHE, Andrade BB, Lana RMQ, et al. (2011). Curvas de disponibilidade de fósforo em solos com diferentes texturas após aplicação de doses crescentes de fosfato monoamônico. Biosci. J. 27: 70-76.

Maia MCC, Resende MDV, Paiva JR, Cavalcanti JJV, et al. (2009). Seleção simultânea para produção, adaptabilidade e estabilidade genotípicas em clones de cajueiro, via modelos mistos. Pesq. Agropec. Trop. 39: 43-50.

Marschner H (1995). Mineral nutrition of higher plants. 2nd edn. Academic Press, London.

Martins LD, Rodrigues WN, Christo LF, Colodetti TV, et al. (2015a). Simultaneous selection of physic nut genotypes (Jatropha curcas L.) for efficient absorption and utilization of N and P. Aust. J. Crop Sci. 9: 248-255.

Martins LD, Rodrigues WN, Machado LS, Brinate SV, et al. (2015b). Evidence of genetic tolerance to low availability of phosphorus in the soil among genotypes of Coffea canephora. Genet. Mol. Res. 14: 10576-10587. PubMed http:// dx.doi.org/10.4238/2015.September.8.19

Novais RF, Neves JCL and Barros NF (1991). Ensaio em ambiente controlado. In: Métodos de pesquisa em fertilidade do solo (Oliveira AJ, Garrido WE, Araújo JD and Lourenço S, eds.). Embrapa/Sae, Brasília, 189-254.

Ramaekers L, Remans R, Rao IM, Blair MW, et al. (2010). Strategies for improving phosphorus acquisition efficiency of crop plants. Field Crops Res. 117: 169-176. http://dx.doi.org/10.1016/j.fcr.2010.03.001

Reis MVM, Damasceno Junior PC, Campos TO, Diegues IP, et al. (2015). Variabilidade genética e associação entre caracteres em germoplasma de pinhão-manso (Jatropha curcas L.). Rev. Cienc. Agron. 46: 412-420.

Resende MDV (2007). SELEGEN-REML/BLUP: sistema estatístico e seleção genética computadorizada via modelos lineares mistos. Embrapa Florestas, Colombo.

Resende ÁV, Furtini Neto AE, Alves VMC, Curi N, et al. (2007). Phosphate efficiency for corn following Brachiaria grass pasture in the Cerrado Region. Better Crops 91: 17-19.

Rosado AM, Rosado TB, Alves AA, Laviola BG, et al. (2012). Seleção simultânea de clones de eucalipto de acordo com produtividade, estabilidade e adaptabilidade. Pesq. Agropec. Bras. 47: 964-971. http://dx.doi.org/10.1590/S0100$\underline{204 X 2012000700013}$

Siddiqi MY and Glass ADM (1981). Utilization index: a modified approach to the estimation and comparison of nutrient utilization efficiency in plants. J. Plant Nutr. 4: 289-302. http://dx.doi.org/10.1080/01904168109362919

Swiader JM, Chyan Y and Freiji FG (1994). Genotypic differences in nitrate uptake and utilization efficiency in pumpkin hybrids. J. Plant Nutr. 17: 1687-1699. http://dx.doi.org/10.1080/01904169409364840

Wani TA, Kitchlu S and Ram G (2012). Genetic variability studies for morphological and qualitative attributes among Jatropha curcas L. accessions grown under subtropical conditions of North India. S. Afr. J. Bot. 79: 102-105. http:// dx.doi.org/10.1016/j.sajb.2011.10.009

Genetics and Molecular Research 15 (3): gmr.15038429 